\title{
AN INTEGRATIVE FRAMEWORK OF PRE-EMPTION STRATEGIES
}

\author{
Khai Sheang Lee, Ph.D. ${ }^{1}$ \\ Irene C. L. Ng, Ph.D. ${ }^{2}$ \\ Lee, Khai S. and Irene C L Ng, (2007), “An Integrative Framework of Pre-Emption Strategies,"
} Journal of Strategic Marketing, Forthcoming

\section{University of Exeter}

Discussion Papers in Management

Paper number 06/02

ISSN 1472-2939

\footnotetext{
** Please direct all correspondences to the second author

${ }^{1}$ Khai-Sheang Lee is Associate Professor, Department of Marketing, Faculty of Business Administration, National University of Singapore, 15 Law Link, FBA1-03-10, Singapore 117591, Tel: (65) 8743163 , Email: bizleeks@,nus.edu.sg.

${ }^{2}$ Irene C L Ng is Senior Lecturer in Marketing at the School of Business and Economics, University of Exeter, Streatham Court, Rennes Drive, Exeter EX4 4PU, United Kingdom Tel: +44 (0) 1392 263250, Fax: +44 (0) 1392 263242, Email: irene.ng@exeter.ac.uk
} 


\title{
AN INTEGRATIVE FRAMEWORK OF PRE-EMPTION STRATEGIES
}

\begin{abstract}
$\underline{\text { Abstract }}$
This paper performs a review of the various pre-emption strategies prescribed in the economics literature. These are cost superiority, consumers' switching cost, channel exclusivity, environmental barriers of entry and credible commitment to react aggressively._Through our analysis, we develop an integrative framework of the pre-emption strategies that will result in long-term payoffs to the firm.

The framework proposes that there are two key dimensions - strategic advantage and strategic focus -- and identify five generic types of pre-emption strategies for market incumbents. These are the switching cost, blockade, credible commitment, tie-up, and cost leadership strategies. The pre-emption strategies and the framework presented can assist managerial decision-making for the successful pre-emption of potential competition to complement their existing efforts.
\end{abstract}

Keywords: $\quad$ Pre-emption, First Mover, Strategic Advantage, Strategic Focus, and Competitive Advantages. 


\title{
AN INTEGRATIVE FRAMEWORK OF PRE-EMPTION STRATEGIES
}

\begin{abstract}
Introduction
Firms achieve a first mover status by being the first to introduce a new product, develop a new process, or enter a new market (Kerin, Varadarajan and Peterson, 1992; Johnson and Scholes, 2002), and first mover advantage often enables pioneering firms to earn sustainable economic profits (Lieberman and Montgomery, 1988). Theoretically, first movers might enjoy the luxury of finding a market for their products and establishing a hold of the market, without having to deal with the complexities that come with the presence of competition. Furthermore, leadership in product and technology, pre-emption of assets, and development of buyer switching costs could be achieved by a first mover (Lieberman and Montgomery, 1988). Those situations are often exploited by pioneering firms to obtain the highest possible returns. Empirical research shows that successful market pioneers generally achieve higher market shares and better business performances than market followers (Lambkin, 1988; Miller et al., 1989; and Kalyanaran et al., 1995).

Yet, it is also known that market pioneers do not always succeed in the long term (Schnaars, 1986). One reason for this is because of competitive entries into the market. Once the attractiveness of a market becomes apparent, competing firms are attracted to enter it. Such entries may erode a pioneer's hold of the market (Lee et al., 2000). This is especially so if a market pioneer has not undertaken pre-emption strategies against later market entrants (Ghemawat, 1986; Kerin et al., 1992; and Urban et al., 1986). Once a market is invaded, the victor is often the firm that has greater resources, deeper pockets, and possesses a more aggressive marketing strategy (Schnaars, 1986; D'aveni, 1995).

In order to achieve a continued monopolistic dominance of the market, pioneers need to pre-empt entry into their markets, even before entries are immediately apparent. Market pioneers need to systematically design, structure, and implement a series of pre-emptive actions to acquire competitive advantages against potential market entrants, or better still, to deter potential entrants from attempting market entry in the first place. Successful pre-emption of market entries by pioneering firms ensures that their hold of the markets endures and a lasting period of aboveaverage profits is achieved (Von Hippel, 1984; Ghemawat, 1986; Lilien and Yoon, 1990; Golder and Tellis, 1993; Begg et al., 2003). Many researchers have studied how firms embark on entry deterrence strategies to deter or slow other firms from entering its market (Bunch and Smiley, 1992). This paper aims to provide an understanding of how market pioneers can successfully preempt market entries (i.e. to prevent potential entrants before they enter its market), in terms of the types of pre-emption strategies that are applicable under different situations.

There is vast literature on market pre-emption that prescribe a variety of strategies (e.g. Lieberman and Montgomery, 1998; and Song et al., 1999). This paper performs an analytic review of these various pre-emption strategies to develop an integrative framework of preemption strategies. Like Porter (1980), our aim for such a framework is to provide a prescriptive guide to managers in strategy decision-making. However, in contrast to Porter's (1980) framework of generic strategies, our framework focuses on pre-emption strategies. Such a framework would be useful for managers in sensitising them to the range of alternative preemption strategies possible, and in assisting them in deciding on the type of pre-emption strategies that are most suitable for their own situations.
\end{abstract}

\section{Literature Review and Analysis}

The topic of entry pre-emption has been extensively researched in both the economics and marketing literature since the pioneering work of Bain (1956). The goal of pre-emption is to deter entry from occurring, and/or to enhance an incumbent's competitive ability against market entrants. Towards this end, various authors have suggested a variety of pre-emption strategies. 
These strategies can be broadly classified based on the advantages acquired by the market incumbent - cost superiority, consumers' switching cost, channel exclusivity, credible commitments, and environmental barriers of entry -- that allow it to successfully deter future entries, and/or defend its position against entries in the event that they occur. We shall therefore review the pre-emption strategies documented in the literature by their bases of competitive advantages.

\section{Preemption Based on Cost Superiority}

Various authors have suggested that market incumbents could successfully pre-empt against market entrants by acquiring a cost superiority over later entrants into the market (Table 1). For example, Rao and Rutenberg (1979) suggested that first movers could achieve cost advantages through economies of scale. This is feasible because of their monopolistic hold of the market, which allows them to achieve higher sales and production volume, and hence generating greater economies of scale. In addition, first movers could derive cost advantages from the economies of scope through brand and product line extensions, ahead of future entries (Thomas, 1996; Perman and Scouller, 1999; Robinson and Chiang, 2002), and/or through savings in direct costs as a result of their marketing mix strategies (Robinson and Fornell, 1985).

\section{(Put Table 1 here)}

Given that first movers have a head start in the market, Ghemawat (1986) suggested that they could also reap cost advantages that result from the learning and experience curve effects. These include increased skill levels and expertise of employees, and the accumulation of resources, ahead of future entries (Miller et al., 1989; Liebermann and Montgomery, 1988). Furthermore, if the skills and expertise acquired could be kept as a secret and/or are firm-specific, then the cost advantages gained could be enduring (Spence, 1981; Peterlaf, 1993; Collis and Montgomery, 1995). An incumbent firm who has achieved a cost advantage could then signal its cost efficiency to potential market entrants through limit pricing (Milgrom and Roberts, 1982b; and Srinivasan, 1991), and excess capacity (Masson and Shaanan, 1986), so as to discourage them from attempting entry.

Pre-emption based on cost superiority, through the various means described, can be a powerful strategy that has been used with great success (Porter, 1981). For example, Porter (1981) reported that the reason Proctor and Gamble was able to maintain its dominance in the disposable diapers market in the US was because of its cost superiority that was acquired ahead of later entrants, through the learning and experience curve effects. While in the financial services industry, Tufano (1989) reported that innovators could charge lower prices and seize higher market shares than imitators because of their lower cost position.

\section{Pre-emption Based on Consumers' Switching Cost}

Several authors have suggested that market pioneers could enhance their competitive positions against future entrants by increasing their consumers' switching cost ahead of future entries (Table 2). Consumers' switching cost could be firm- or brand-specific and refers to the cost faced by existing users if they switch brands, and is therefore an indicator of consumers' reluctance to switch from one brand to another. Pre-emption strategies that increase consumers' switching cost can be effective in deterring entries because, when consumers' switching cost for a pioneer's products is high, later entrants into the market will have to utilise a significant amount of extra resources to persuade buyers to change brand (Liebermann and Montgomery, 1988; Neven, 1989). This is true even if other barriers to entry are low. For example, Makadok (1998) suggested that in the money market mutual fund industry, where the barriers to entry are low, pioneering advantages could still be achieved by increasing customers' switching costs, which therefore restricts accessibility to existing customers by later market entrants.

\section{(Put Table 2 here)}

There are several ways by which incumbent firms could increase the switching cost of their existing customers. Wernerfelt (1985) suggested that effective pre-emption could be achieved by designing products that require users to invest time and effort in learning to use them

$$
2
$$

\footnotetext{
Lee, Khai S. and Irene C L Ng, (2007), "An Integrative Framework of Pre-Emption Strategies," Journal of
} Strategic Marketing, Forthcoming 
effectively, and making such skills and knowledge acquired to be brand specific. Pioneering firms could also increase consumers' switching cost by designing their products in a way that they require supplementary products that are brand specific. For example, by customising batteries and chargers so that they are specific to a particular brand of hand-phones, and designing software to be specific to a brand of computers (Klemperer, 1987; Kerin et al., 1992), consumers' switching costs would be increased, thereby discouraging them from switching to another brand.

In addition, Schmalensee (1982) suggested that by being first in the market, pioneering firms have the opportunity to establish their products as the standard against which future products are judged. Alpert (1987) suggested that a pioneering advantage could also be achieved by enhancing the recall of the pioneer's brand, such that the brand becomes an exemplar that comes to mind more readily than other brands. This is most effective, the author suggested, if the brand becomes generalisable to the entire product class. Such arguments are consistent with the result of Carpenter and Nakamoto's empirical study (1989), which showed that customers' perceptions can be influenced in a way that a pioneer's product can be perceived as prototypical of the product category.

Consumers' switching cost could also be increased through a firm's investments in building a strong brand image and brand loyalty for its products (Neven, 1989, and Wernerfelt, 1991). Krouse (1984) argued that the creation and sustenance of a brand and its reputation essentially assured customers that the necessary quality level would be provided, an assurance that new entrants were denied. In addition, for many convenience goods and low-to-medium involvement products, when brand loyalty is strong, buyers do not spend excessive time to search for a superior product. Instead, they rely on the brand image as a signal of product quality. A strong brand image therefore causes consumers to be reluctant to try new and littleknown brands. This is especially true for services because of their intangibility, and consumers' perceptions that quality uncertainty and risk of purchase are greater for services than for physical products (Mitchell and Greatorex, 1990; and Murray and Schachter, 1990).

For experience-type goods (Nelson, 1970, and 1974) which generally carry a higher risk of purchase compared to search-type goods, Conrad (1983) showed that consumers are prepared to pay a price premium for pioneering brands, as they are more knowledgeable of these brands than of later brands. This suggests that a market pioneer, by investing in promotions to inform and educate consumers about its brand, could increase consumers' switching costs for its brand (Conrad, 1983; and Schmalensee, 1982), and block consumers from trying out later brands that come into the market (Hoch and Deighton, 1989). Late entrants attempting to persuade consumers to switch brands would therefore encounter resistance, as the idea of switching and having to get used to a new brand becomes unappealing (Schmalensee, 1982).

Pioneering firms could also increase consumers' switching cost by imposing penalties on consumers switching to other brands. For example, a firm could impose transaction costs on a customer by charging him for services rendered in closing a bank account (Klemperer, 1987). Alternatively, firms could also increase consumers' switching cost by providing incentives for the repeated use and purchase of their products. For example, credit card companies are known to reward their clients with "usage points" that depend on card spending. These points could be used to exchange for gifts, to purchase other products at reduced prices, or to reduce the card's annual subscription rate. Similar customer retention strategies have been implemented by some airlines in the form of "frequent flier" programmes to encourage repeat purchases (Klemperer, 1986). As existing customers might lose the accumulated incentives by switching to other brands, customer retention programmes can therefore be effective in preventing them from trying other brands that enter the market later.

Apart from the strategies above, network effects on the order of entry are also discussed in recent years. The term 'network effects' refer to how the value of a product depends on how many users use it. The values of a product will increase as more users use or own the product (Katz and Shapiro 1985). For example, the value of Microsoft Windows will be enhanced when more people use it as a platform. Lee and O'Connor (2003) pointed out that network effects might occur in certain industries (e.g. information technology) and switching costs might positively

$$
3
$$

Lee, Khai S. and Irene C L Ng, (2007), "An Integrative Framework of Pre-Emption Strategies," Journal of Strategic Marketing, Forthcoming 
depend more on network size. Therefore, once a product is widely used by customers and the value of the product increases with the number of users, this raises switching costs and thus deters consumers from adopting other products. Although network effects might increase the switching costs of customers, Lee and O'Connor (2003) further indicated that market pioneers might lose their advantages if new entrants are able to build networks quickly. Yet, if a market pioneer can establish a strong network base, market entry might become difficult due to customers' reluctance to adopt new products. Some other researchers also address the advantages of network effects. For example, Shankar and Bayus (2003) conducted an empirical research of the home video game industry to show that network strength (the marginal impact of increasing in network size on demand) will positively affect customers' demand and the effectiveness of a firm's pricing and advertising. By improving network strength, network effects could be enhanced and therefore allow customers to enjoy more benefits from the same products, thus further increasing switching costs.

\section{Pre-emption Based on Channel Exclusivity}

Market pioneers are well placed to gain an advantage based on exclusivity in supplies and distribution, as they have the first claim to scarce resources and market access factors. Liebermann and Montgomery (1988) suggested that by controlling access to critical supplies and to channels of distribution, thus causing potential entrants to be largely handicapped if they still choose to enter the market, entry could be averted. Superior access to suppliers and preferred access to markets not only restricts channel access by later entrants (Ghemawat, 1986); they also increase the cost of entry to potential market entrants (Neven, 1989).

(Put Table 3 here)

Several ways to achieve channel exclusivity have been suggested by various authors (Table 3). A market pioneer could gain control of access to supply and distribution channels through exclusivity contracts that provide incentives to channel members in exchange for their commitment to an exclusive exchange relationship in terms of supply or brand representation (Porter, 1974). Resources permitting, a market pioneer could also achieve channel control through vertical and/or horizontal integration (Ghemawat, 1986; Lieberman and Montgomery, 1988).

From the literature on transaction cost economics (Williamson, 1981), it could also be inferred that, by investing in brand-specific assets ahead of future entries, a first mover could achieve channel control. Assets like technical skills, product and market knowledge, and customer relationships, if specific to a market pioneer or its brand, have little or no salvage value for channel members in exchange relationships with firms other than the market pioneer (Williamson, 1981). The build-up of such assets by a market pioneer thus makes channel members less willing to switch allegiance to later entrants into the market. This therefore results in channel members being locked into the exchange relationship (Stump and Heide, 1996; Williamson, 1979) with the pioneering firm, which accords the latter a distribution advantage.

Yet another way of achieving a distribution advantage is by covering every available 'space' or market opportunity ahead of future entries (Prescott and Visscher, 1977; Schmalensee, 1978). This requires that a market pioneer follows a product proliferation strategy (Neven, 1989) in which it pre-emptively fills in all profitable market segments and niches that later entrants may be attracted to, offering each of these segments a differentiated product (Schmalensee, 1982, and Robinson and Fornell, 1985). In addition, such a strategy allows a pioneering firm to exploit its brand equity and to benefit from cost reductions that result from the economies of scope (Thomas, 1996; Robinson and Chiang, 2002).

The literature on spatial competition (e.g. Schmalensee, 1978; Lane, 1980; and Urban et al., 1986; Brito, 2003) also suggested that market pioneers can pre-empt entry by being the first to occupy preferred locations. This is especially important at the retail level where strategic retail locations are scarce. In addition, a product extension strategy of introducing multiple products and product lines maximises occupation of retailers' shelf-space (White, 1983) and thus restricts access by later entrants. Extending this argument, Robinson and Fornell (1985) suggested that 
pioneering firms follow an intensive distribution strategy to dominate shelf-space in order to preempt later entries. Other than maximising occupation of retail shelf-space, a broad product line also requires channel intermediaries to commit greater time and resources to its marketing, and hence reduces their ability to devote significant commitments to new brands introduced by later market entrants.

\section{Pre-emption Based on Environmental Barriers of Entry}

Potential entrants into a market could be denied access if there are substantial barriers to entry that are due to environmental factors. The presence of such entry barriers requires that "additional resources must expended by a non-pioneering firm, beyond those required under conditions of simultaneous entry, to compete effectively in the market place relative to the first mover" (Kerin et al., 1992, p34). To the extent that the resource requirements for entry are sufficiently high, entry is effectively denied.

$$
\text { (Put Table } 4 \text { here) }
$$

In the literature, various authors (Table 4) have examined the impact of environmental factors as entry barriers. For example, Ghemawat (1986) suggested that market pioneers could deter entry by being on the right side of governmental policies. Governmental policies can be effective barriers to entry, by imposing stringent conditions and constraints, which later market entrants find impossible to comply with. As such, businesses that are on the correct side of public policy could influence governmental regulations to their advantage (Ghemawat, 1986).

Continued investments in research and technological improvements to the product and/or processes could also serve as entry barriers to potential market entrants. Continued productive R\&D could serve as a credible signal of an incumbent's ability to overtake any rivals considering a similar research programme (Gilbert and Newberry, 1982; Karakaya, 2002; Begg et al., 2003), and results in perceived technological superiority (Lieberman and Montgomery, 1988). Entry deterrence could also be achieved when technological improvements resulting from proprietary R\&D efforts undertaken can be patented or kept as a trade secret (Gilbert and Newbery, 1982). In the drug industry for example, Gorecki (1986) found that prescription drugs enjoyed tremendous pioneering advantages, in part due to patent protections. Neven (1989) also proposed that pioneering firms deter entries by denying access by later entrants to technology through patent protection, without which competitive advantages based on technology are not sustainable. This is because the diffusion of technology occurs swiftly in many industries as a result of 'reverse engineering', workforce mobility, research publications, and informal technical communications (Liebermann and Montgomery, 1988).

Extending the argument for the use of patents to deter entries, Bresnahan (1985) suggested that not only the technology directly relevant to the product or process could be patented; alternative technologies should also be patented so that potential entrants are effectively blocked from entry. The author cited the case of Xerox, which patented a host of alternative technologies in addition to those crucial to its basic Xerography process. So successful was Xerox in preventing entries into the industry, that challengers have resorted to anti-trust actions to force it to license its technology (Bresnahan, 1985; Hill, 2005).

In markets where market information is not readily available or can only be acquired at high costs, the lack of market information itself could be a barrier to entry (McGahan, 1993). The lack of market information translates into greater uncertainty and business risks for new entrants, putting them at a disadvantage compared to incumbent firms. For this reason, McGahan (1993) suggested that demand information could be kept proprietary by an incumbent in order to deter entry. The author's argument can be extended to include any information that pertains to market access and attractiveness - like suppliers, intermediaries, market contacts, demand, etc., which pioneering firms should keep private.

\section{Pre-emption Based on Credible Commitment to React Aggressively \\ In general, market entry decisions are made based on an evaluation of the attractiveness of the market targeted for entry. Hence, potential entrants might be discouraged from entry, if an}

Lee, Khai S. and Irene C L Ng, (2007), "An Integrative Framework of Pre-Emption Strategies," Journal of Strategic Marketing, Forthcoming 
incumbent could credibly convey to them that the market being targeted would be made unattractive if indeed they entered it. A market pioneer could achieve this by credibly committing to defend its market position, and signaling its intent to react aggressively to any market intrusions made by later entrants. Kreps and Wilson (1982) have showed that if an incumbent has a strong reputation for being adversary over time (e.g. adopting predatory pricing to deter later entrants), its aggressive reputation can serve as a threat to impede other entries. Aggressive reactions by an incumbent firm to reduce the attractiveness of the market targeted include increasing the cost and risk of entry. Hence, threats to carry out such reactions, if credible, can influence the entry decisions of later entrants (Spence, 1979; Hultink and Langerak 2002).

(Put Table 5 here)

In the economics literature on entry deterrence, various authors have identified several ways to achieve credible commitment to react aggressively to entry (Table 5). Credible commitments are those that obligate an incumbent firm to aggressively defend its market position against any entry attempts being made, even if short-term losses are incurred. Dixit (1979) suggested that a first mover's investments in excess capacity serve as a credible threat of lowered prices and post-entry profitability. Dixit (1980) further argued that irrevocable commitment of investment alters the initial conditions of the post-entry game to the advantage of the incumbent, thus achieving entry deterrence.

Consistent with Dixit's arguments, Eaton and Lipsey (1979) showed that capacity expansion, just at the point in time when entry is profitable, deters entry and is profit maximising for an incumbent firm. Ghemawat's (1984) study provided empirical support for Eaton and Lipsey's suggestion that capacity expansion by incumbent firms deters entry. In a further study, Eaton and Lipsey (1980) also suggested that irreversible investments serve as credible exit barriers that commit an incumbent to defend its market, which therefore deter entries. In support of this argument, an empirical study by Ghemawat (1986) showed that market pioneers could credibly signal their commitment to defend their market against potential entrants through durable investments.

Other than through irrevocable investments in fixed assets, Selten (1978) suggested that a first mover could credibly signal its commitment to defend its market by acquiring a "reputation for toughness". This refers to a firm's reputation for taking aggressive reactions against attempted entries into its market. Similarly, Milgrom and Roberts (1982a) suggested that entry can be deterred if a firm exhibits some behavioural rule, like being a "fanatical predator". A reputation for aggressive retaliation against entry could be achieved through a history of aggressive behaviours against competitors - like engaging in price wars, predatory pricing, and major marketing campaigns. Such a reputation could be effective in entry deterrence as it increases the cost and risk of entry into a market supplied by an aggressive incumbent firm, to the extent that potential entrants are convinced that entry is just not worth trying. However, the reputation of being aggressive might not be useful in every situation. Clark and Montgomery (1998) claimed that reputation is less useful when entrants have greater knowledge of incumbent firms. Their study showed that the relationship between entrants' behaviour and reputation is not as clear as thought previously.

Apart from establishing a strong reputation to deter new entries, some researchers propose that incumbents who signal their intentions to preempt may be able to frustrate potential rivals. For example, Heil and Robertson (1991) indicated that incumbent firms' ability to develop barriers to new entries and the credibility of such pre-emptive signals will determine the likelihood of achieving pre-emptive advantage. Clearly, factors such as signalling commitment, signalling reputation, signal consistency, signal clarity, signal aggressiveness, and the attributes of signal receivers will also affect how signal receivers interpret them (Heil and Robertson, 1991).

\section{A Framework of Pre-emption Strategies}

Market pioneers enjoy a unique opportunity not available to all later entrants, which is the opportunity to pre-empt the arrival of other competitors. From the literature review and analysis, several bases of advantages are identified, upon which successful pre-emption of entry could be

6

Lee, Khai S. and Irene C L Ng, (2007), "An Integrative Framework of Pre-Emption Strategies," Journal of Strategic Marketing, Forthcoming 
achieved. We propose that the various pre-emption strategies reviewed can be categorised along two dimensions - strategic advantage and strategic focus. We define strategic advantages as those advantages possessed by an incumbent firm that allow it to effectively deter and/or sustain its position against future entries. Such advantages can further be classified into two types - exclusivity and cost superiority, which we define as follows:

(i) Exclusivity: A strategic advantage that allows market incumbents to restrict market access to later entrants.

Cost Superiority: A strategic advantage based on a low-cost position acquired by market incumbents.

Our proposed dimension of strategic advantage is not unlike that proposed by Porter (1980), who suggested that cost superiority and "uniqueness as perceived by customers" were important in competing for markets. However, we propose that a firm's unique or exclusive position can be achieved in several ways, other than through customers' perceptions alone. As our analysis of the literature illustrates, an incumbent can acquire a strategic advantage in exclusivity by increasing consumers' switching cost, controlling access to critical supplies and to channels of distribution, exploiting market environmental factors to create barriers to entry, and making credible commitments to react aggressively to entry. Uniqueness of consumers' perceptions is but one way to increasing consumers' switching costs.

Our analysis of the literature also suggests that a market pioneer's strategic advantages in exclusivity depend on the focus of its pre-emptive actions. By focusing on the consumer, channel, itself internally, and/or market environment, an incumbent can achieve strategic advantages in switching cost, distribution, credible commitment, and/or environmental barriers to entry, respectively, to preempt entry. Hence, in contrast to Porter's (1980) framework of generic strategies in which one of the key dimensions is strategic target, we propose that another key dimension of our framework of pre-emption strategies is strategic focus. An incumbent's strategic focus can thus be viewed as the key area(s) - consumers, channel, internal, and/or environment - on which it can concentrate to acquire a strategic advantage(s) to pre-empt entry.

Based on the two dimensions of strategic advantage and strategic focus, we therefore present a four by two $(4 \times 2)$ framework of pre-emption strategies, from which five generic- type pre-emption strategies for incumbent firms (Figure 1) can be identified. These strategies are: (i) the cost leadership strategy, (ii) the switching cost strategy, (iii) the tie-up strategy, (iv) the credible commitment strategy, and (v) the blockade strategy.

(Put Figure 1 here)

(1) Cost Leadership Strategy: A strategy that focuses on consumers and channel members, offering them more attractive pricing terms than that could be offered by later market entrants.

A cost leadership strategy as a pre-emption strategy requires that a market incumbent focuses on its consumers and channel members, offering them more attractive pricing terms than could be offered by later market entrants. This is feasible if an incumbent possesses a cost superiority over later entrants into the market. An analysis of the literature suggests that an incumbent could achieve cost superiority in several ways. For example, it could be achieved through economies of scale and scope (Rao and Rutenberg, 1979; Thomas, 1996; Robinson and Chiang, 2002), and learning and experience curve effects (Spence, 1981; and Ghemawat, 1986). Cost superiority could also be achieved through the acquisition of appropriate skills and expertise (Miller et al., 1989; and Liebermann and Montgomery, 1988), production technology upgrades and product designs (Gilbert and Newbery, 1982), distribution efficiencies (Robinson and Fornell, 1985), and appropriate sourcing strategies (Ghemawat, 1986; and Liebermann and Montgomery, 1988).

$$
7
$$

Lee, Khai S. and Irene C L Ng, (2007), “An Integrative Framework of Pre-Emption Strategies," Journal of Strategic Marketing, Forthcoming 
(2) Switching Cost Strategy: A strategy that focuses on consumers to build up their cost of switching to brands/products offered by later market entrants.

In following a switching cost strategy, a pioneering firm focuses on its consumers to build up their cost of switching to brands, products, and/or services, offered by later market entrants. A high switching cost makes consumers reluctant to change brands, unless they are compensated for the cost of switching. This places a price pressure on later market entrants, who have to significantly reduce their prices in order to induce consumers to switch to and try their brands. A high switching cost could be achieved by investing in brand equity and loyalty (Neven, 1989; Schmalensee, 1982; Hoch and Deighton, 1989; and Wernerfelt, 1985, and 1991), increasing brand rememberability (Alpert, 1987), increasing consumers' knowledge and confidence of product quality (Conrad, 1983; and Krouse, 1984), and framing consumers' perceptions (Carpenter and Nakamoto, 1989). Consumers' switching cost could also be increased by increasing their product-specific investments (Conrad, 1983; and Wernerfelt, 1985; and Liebermann and Montgomery, 1988), providing incentives for repeat use and purchase (Klemperer, 1986), and designing products such that they require supplementary products that are captive. Consumers' switching costs can be also increased through bundling products or increasing the potential of losing benefits or money (Burnham, Frels, Mahajan, 2003). Finally, network effects also enhance consumers' switching costs when customers can obtain more benefits from having more people use the same products (Lee and O'Connor, 2003).

(3) Tie-Up Strategy: A strategy that focuses on channel members to gain their exclusive commitment to a market incumbent.

As with the switching cost strategy, the tie-up strategy aims to prevent channel members from changing their allegiance to other brands/firms that enter the market later. However, in contrast to the switching cost strategy, the tie-up strategy focuses on channel members, including suppliers and channel intermediaries. By preventing channel members from committing to brands, products, and/or services offered by later market entrants, a tie-up strategy thus restricts the market access of entrants to suppliers and channel intermediaries. Control of access to market channels could be achieved through exclusivity contracts (Porter, 1974; and Ghemawat, 1986), vertical and horizontal integration (Ghemawat, 1986), investments in brand-specific assets (Stump and Heide, 1996), and tie-up of scarce resources (Liebermann and Montgomery, 1988). It could also be achieved through spatial pre-emption of attractive market segments, retail locations (Prescott and Visscher, 1977; Schmalensee, 1978; Lane, 1980; and Thomas, 1996) and retailers' shelf-space (White, 1983; and Robinson and Fornell, 1985).

(4) Credible Commitment Strategy: A strategy to influence entry decisions by conveying a credible threat of aggressive reactions to entries.

While the pre-emption strategies described earlier focus on consumers and channel members, a credible commitment strategy requires a market incumbent to credibly commit itself to undertake aggressive reactions, should entries be attempted, and to convey such a threat to potential entrants in advance, in order to deter entry attempts.

A market incumbent's threat of aggressive reactions to entries is credible if it possesses a "reputation for toughness" (Selten, 1978), or is known to be a "fanatical predator" (Milgrom and Roberts, 1982a). Such a reputation could be acquired through past aggressive behaviours in competition. A firm's threat of aggressive reactions is also credible, if it possesses a cost superiority (Milgrom and Roberts, 1982b), as this increases its chances of success against attempted entries. In addition, strategic investments in irrevocable assets, or pre-emptive investments, would commit an incumbent firm to react aggressively against entries (Spence, 1977 and 1979; Dixit, 1980; Masson and Shaanan, 1986; Reynolds, 1987; and Neven, 1989). This is credible because, by incurring such investments, a market incumbent would suffer an even greater reduction in profitability if it chooses to accommodate entries (by not reacting

$$
8
$$

Lee, Khai S. and Irene C L Ng, (2007), "An Integrative Framework of Pre-Emption Strategies," Journal of Strategic Marketing, Forthcoming 
aggressively), than if it chooses to react aggressively to entries. In this regard, investments in excess capacity (Dixit, 1979), capacity expansion just prior to entry by competitors (Eaton and Lipsey, 1979), and creation of exit barriers (Eaton and Lipsey, 1980), serve as signals of a market incumbent's readiness to aggressively defend its market.

(5) Blockade Strategy: A strategy that focuses on the market environmental factors to capitalise on and/or influence them in such a way as to gain strategic advantages.

In contrast to all the above pre-emption strategies, a pioneering firm following a blockade strategy focuses on the market environmental factors, with the aim of capitalising on and/or influencing them in such a way as to gain strategic advantages over later entrants. Towards this end, a pioneering firm could patent its core technology (Gilbert and Newbery, 1982; and Neven, 1989) as well as alternative ones (Bresnahan, 1985). Market incumbents could also lobby for governmental policies that restrict market access to later entrants and/or confer benefits to market pioneers (Ghemawat, 1986). In addition, by keeping private important demand information (McGahan, 1993), the risk of entry faced by later entrants would be increased due the greater uncertainties they face when market information is lacking.

(Put Figure 2 here)

Figure 2 provides a summary of the various pre-emption strategies described, in terms of their objectives, foci, and the means by which they could be achieved.

\section{Discussion and Conclusion}

Of the five pre-emption strategies identified above, which of these strategies (or a combination of) a market incumbent should follow depends on a number of factors. First of all, the pre-emption strategy intended should be permissible. In some countries, anti-trust acts will prevent the use of some of the pre-emption strategies suggested. Another consideration is the long-term payoffs associated with the use of a particular pre-emption strategy. Obviously, a market incumbent firm should select the pre-emption strategy that maximises its payoffs over the long term. On the other hand, the pre-emption strategy that is potentially the most profitable may be costly to implement. Hence, a firm's available resources need to be taken into account also (Robinson et al., 1992; Lieberman and Montgomery, 1998). A firm's core competencies will also affect its choice of pre-emption strategy, as one based on a firm's existing core competencies is more readily implemented with lower cost. A pre-emption strategy that is consistent with an industry's key success factor(s) will be more effective, and hence this also needs to be taken into consideration.

In deterring entries from occurring in the first place, it is important that potential entrants read a market incumbent's signals of commitment correctly. Otherwise, once market entry has occurred (mistakenly or otherwise), the "sunk" investments made by the entrant may pose as a formidable exit barrier. This commits the entrant to carving out a position, even though it may be disadvantaged compared to the incumbent firm. Under such a situation, an aggressive response by an incumbent will potentially result in a prolonged and intense competition that is costly to both the incumbent and the new entrant. Hence, it is important that an incumbent ensures that potential entrants do not misread its intended intensity of aggressive response. For this purpose, pre-announcements become necessary, to convince potential entrants to defer their entries (Eliashberg and Robertson, 1988). Network effect is another issue that incumbent firms need to take into account. Launching a product with strong network effects will affect customers' switching cost directly, and a strong network will become a significant barrier to new entrants as well.

To pre-empt entries, firms have to be pro-active. By undertaking pre-emption strategies, much resources and effort may be saved if entries can be successfully deterred. Although the literature contains numerous and diverse prescriptions as to how pioneering firms can pre-empt entries, little has been done to synthesise the literature into a coherent structure that is useful in providing managerial guidance and directions. Hence, by presenting an integrative framework based on an analytic review of the existing literature, our paper aims to provide a prescriptive 
guide for managers in formulating pre-emption strategies to protect their markets. In addition, our paper provides problems of application in terms of the five pre-emption strategies (Table 6).

(Put Table 6 here)

Based on our literature review and the discussion above, we further submit that incumbent firms should take into account three factors before they practice the five pre-emption strategies. The three factors are: Internal factors, external factors, and cognitive factors. Internal factors refer to the long-term payoffs of incumbent firms, the complexity of organisational structure, the core competition of incumbent firms, managerial problems of practicing pre-emption strategies, the ability of practicing pre-emption strategies, sunk cost, and network effects of products. External factors refer to issues such as anti-trust law, public opinion, governmental policies, the need of customers, the development of technology, free rider problem, and the competitive level of market. Finally, cognitive factors relate to the new entrants' expectations of incumbent firms' signalling.

Karakaya and Stahl (1989) have found that five barriers (cost advantages of incumbents, product differentiation of incumbents, customer switching costs, access to distribution channels, and government policy) could make a difference in pre-empting entry into consumer and industrial goods markets. Yet the specific application timing of the five strategies varies in different situations. There seem to be no single criterion for comparing which strategy is better than the other in a dynamic market. Hence, before incumbent firms embark on any of the five preemption strategies, we suggest that these three factors be considered to guide their use.

The framework proposed and the pre-emption strategies identified also assist managerial decision-making by sensitising managers to the range of alternative pre-emption strategies that may potentially be suitable to their situations. In addition, the proposed framework provides managers with directions as to the area(s) to focus (the strategic focus), and the bases for successful pre-emption (the strategic advantage), in devising effective pre-emption strategies. Finally, the framework serves as a benchmark for managers to assess the adequacy of their existing pre-emptive efforts, and to identify alternatives that complement their existing efforts. 


\section{References}

Aghion, P. and Bolton, P. (1987) Contracts as a Barrier to Entry. American Economic Review. 77(3): 388-401

Alpert, F. (1987) Product Categories, Product Hierarchy, and Partnership: A Consumer Behavior Explanation for Pioneer Brand Advantage. In Susan P. Douglas et al., AMA Educators' Proceedings 133-138. American Marketing Association: Chicago.

Bain, J. (1956) Barriers to New Competition. Harvard University Press: Cambridge MA.

Begg, D., Fisher, S. \& Dornbusch, R. (2003) Economics, 7ed. Publisher: McGraw-Hill Education.

Bresnahan, T.F. (1985) Post-entry competition in the plain paper copier market. American Economic Review 75: 15-19.

Brito, D. (2003) Preemptive Mergers Under Spatial Competition. International Journal of Industrial Organization 21(10): 1601-1622.

Bunch, D.S. and Smiley, R. (1992) Who Deters Entry? Evidence of the Use of Strategic Entry Deterrence. Review of Economics and Statistics 3(August): 509-521.

Burnham, T. A.; Frels, J. K. \& Mahajan, V. (2003) Consumer Switching Costs: A Typology, Antecedents, and Consequences. Journal of the Academy of Marketing Science 31: 109-126.

Carpenter, G.S. \& Nakamoto, K. (1989) Consumer Preference Formation and Pioneering Advantage. Journal of Marketing Research 26(August): 285-298.

Clark, B.H. and Montgomery D.B. (1998) Deterrence, Reputations and Competitive Cognition. Management Science 44(1): 62-82.

Collis, D. J. and Montgomery, C. A. (1995) Competing on resources: Strategy in the 1990s. Harvard Business Review 19, 118-128.

Conrad, C. (1983) The Advantage of Being First and Competition Between Firms. International Journal of Industrial Organisation 1: 353-364.

D'Aveni, R. (1995) Hypercompetition (hardcover) or Hypercompetitive Rivalries (paperback), Free Press, New York.

Davies, J.E. (1986) Competition, Contestability and the Liner Shipping Industry. Journal of Transport Economics and Policy 20: 299-312.

Dixit, A. (1979) A Model of Duopoly Suggesting a Theory of Entry Barriers. Journal of Economics 10: $20-32$.

Dixit, A. (1980) The Role of Investment in Entry Deterrence. Economic Journal 90: 95-106.

Eaton, B.C. and Lipsey, R. (1979) The Theory of Market Presumption: The Persistence of Excess Capacity and Monopoly in Growing Spatial Markets. Economica 46: 149-158. 
Eaton, B.C. and Lipsey, R. (1980) Exit Barriers are Entry Barriers: The Durability of Capital as a Barrier to Entry. Bell Journal of Economics 11: 721-729.

Eliashberg, J. and Robertson, T.S. (1988) New Product Pre-announcing Behavior: A Market Signaling Study. Journal of Marketing Research 25(Aug): 282-292.

Ghemawat, P. (1984) Capacity expansion in the titanium dioxide industry. Journal of Industrial Economics 33(Dec): 145-163.

Ghemawat, P. (1986) Sustainable Advantage. Harvard Business Review Sep-Oct: 53-58.

Gilbert, R.J. and Newbery, D.M.G. (1982) Preemptive patenting and the persistence of monopoly. American Economic Review 72(June): 514-526.

Golder, P.N., and Tellis, G.J. (1993) Pioneer Advantage: Marketing Logic or Marketing Legend?. Journal of Marketing Research 30(May): 158-170.

Gorecki, P.K. (1986) The Importance of Being First. International Journal of Industrial Organisation 4: 371-393.

Heil, O. and Robertson, T.S. (1991) Toward a theory of competitive market Signalling. Strategic Management Journal 12: 403-418.

Hill, C., (2005) International Business: Competing in the Global Marketplace $5^{\text {th }}$ ed. New York: MacGraw-Hill//rwin.Hoch, S. and Deighton, J. (1989). Managing What Consumers Learn from Experience. Journal of Marketing 53(April): 1-20.

Hultink, E. J. and Langerak, F. (2002) Launch Decisions and Competitive Reactions: An Exploratory Market Signaling Study. Journal of Product Innovation Management 19 (3): 199212.

Johnson, G. and Scholes, K., (2002) Exploring corporate strategy: text and cases. $6^{\mathrm{TH}}$ ed. London: Prentice Hall.Kalyanaram, G.; Robinson, W.T. and Urban, G.L. (1995). Order of Market Entry: Established Empirical Generalizations, Emerging Empirical Generalizations and Future Research. Marketing Science 14(3, Part 2 of 2).

Karakaya, F. and Stahl, M.J. (1989) Barriers to Entry and Market Entry Decisions in Consumer and Industrial Goods Markets. Journal of Marketing 53 (April): 80-91.

Karakaya, F. (2002) Barriers to Entry in Industrial Markets. Journal of Business and Industrial Marketing 17(5): 379-388.

Katz, M. and Shapiro, C. (1985) Network Externalities, Competition, and Compatibility. The American Economic Review 75 (3): 424-440.

Keaveney, S.M. (1995) Customer Switching Behavior in Service Industries: An Exploratory Study. Journal of Marketing 59 (April): 71-82.

Kerin, R.A.; Varadarajan, R.R. and Peterson, R.A. (1992) First-Mover Advantage: A Synthesis, Conceptual Framework and Research Propositions. Journal of Marketing 56: 33-52.

12

Lee, Khai S. and Irene C L Ng, (2007), "An Integrative Framework of Pre-Emption Strategies," Journal of Strategic Marketing, Forthcoming 
Klemperer, P.D. (1986) Markets with Consumer Switching Costs. Ph.D. dissertation, Stanford University.

Klemperer, P.D. (1987) The Competitiveness of Markets with Switching Costs. Rand Journal of Economics 18(1, Spring): 138-150.

Kreps, D. and Wilson, R. (1982) Reputation and Imperfect Information. Journal of Economic Theory 27: 253-279.

Krouse, C.G. (1984) Brand Name as a Barrier to Entry: The ReaLemon Case. Southern Economic Journal 51(Oct): 495-502.

Lambkin, M. (1988) Order of Entry and Performance in New Markets. Strategic Management Journal 9: 127-140.

Lane, W. (1980) Product Differentiation in a market with endogenous sequential entry. Bell Journal of Economics 11: 237-260.

Lee, H.; Smith, K.G.; Grimm, C.M.; Schomburg, A. (2000) Timing, Order and Durability of New Product Advantages with Imitation. Strategic Management Journal 21: 23-30.

Lee, Yikuan and O'Connor, G.C. (2003) New Product Launch Strategy for Network Effects. Products. Academy of Marketing Science Journal 31 (3): 241-256.

Lieberman, M.B. and Montgomery, D.B. (1988) First-Mover Advantages. Strategic Management Journal 9: 41-58.

Lieberman, M.B. and Montgomery, D.B. (1998) First Mover (Dis)advantages: Retrospective and Link with the Resource Based View. Strategic Management Journal 19: 1111-1125.

Lilien, G.L. and Yoon, E. (1990) The Timing of Competitive Market Entry: An Exploratory Study of New Industrial Products. Management Science 36(5): 568-585.

Lin, Z. and Carley, K. (1997) Organizational Response: The Cost Performance Tradeoff. Management Science. 43(2): 217-234.

Makadok R. (1998) Can First-Mover and Early-Mover Advantages be Sustained in an Industry with Low Barriers to Entry/Imitation. Strategic Management Journal 19: 683-696.

Masson, R. \& Shaanan, J. (1986) Excess Capacity and Limit Pricing: An Empirical Test. Economica 53: 365-378.

McGahan, A.M. (1993) The Effect of incomplete information about demand on preemption. International Journal of Industrial Organization 11: 327-346.

Milgrom, P. and Roberts, J. (1982a) Predation, Reputation and Entry Deterrence. Journal of Economic Theory 27: 280-312.

Milgrom, P. and Roberts, J. (1982b) Limit Pricing and Entry Under Incomplete Information: An Equilibrium Analysis. Econometrica 50: 443-459. 
Miller, A.; Gartner, W.B. and Wilson, R. (1989) Entry Order, Market Share and Competitive Advantage: A Study of Their Relationship in New Corporate Ventures. Journal of Business Venturing 4(May): 197-209.

Mitchell, V.W. and Greatorex, M. (1993) Risk Perception and Reduction in the Purchase of Consumer Services. The Service Industries Journal 13(4, Oct): 179-200.

Murray, K.B. and Schachter, J.L. (1990) The Impact of Services Versus Goods on Consumers' Assessment of Perceived Risk and Variability. Journal of the Academy of Marketing Science 18(Winter): 51-65.

Nelson, P. (1970). Information and Consumer Behavior Journal of Political Economy 78: 311-329.

Nelson, P. (1974). Advertising as Information Journal of Political Economy 82(Jul/Aug): 729-754.

Neven, D. 1987 Endogenous sequential entry in a Spatial Model. The International Journal of Industrial Organization 4: 419-434.

Neven D. 1989 Strategic Entry Deterrence: Recent Developments in the Economics of Industry. Journal of Economic Surveys 3: 213-233.

Pedro, L.M. and Sicotte, R. (2003) Exclusive Contracts And Market Power: Evidence From Ocean Shipping. The Journal of Industrial Economics 51: 193-213.

Perman, R. and Scouller, J., (1999) Business Economics. Oxford: Oxford University Press.

Peterlaf, M., (1993) The cornerstones of competitive advantage: a resource-based view, Strategic Management Journal, 14, 179-191.

Porter, M. (1974) Consumer Behavior, Retailer Power and Market Performance in Consumer Goods Industries. Review of Economics and Statistics 56: 419-436.

Porter, M. (1976) Interbrand Choice, Strategy and Bilateral Market Power. Harvard University Press: Cambridge MA.

Porter, M. (1980) Competitive Strategy: Techniques for Analyzing Industries and Competitors. Free Press: New York.

Porter, M. (1981) Strategic interaction: Some lessons from industry histories for theory and antitrust policy. In S. Salop, Strategy, Predation and Anti-Trust Analysis. Washington: FTC.

Posner, R.A. (1981) The Next Step in the Antitrust Treatment of Restricted Distribution: Per se Legality. University of Chicago Law Review 48: 6-26.

Prescott, E. and Visscher, M. (1977) Sequential location among firms with foresight. Bell Journal of Economics 8: 378-393.

Rao, R.C. and Rutenberg, D.P. (1979) Preemption Alert Rival: Strategic Timing of the First Plant by Analysis of Sophisticated Rivalry. Bell Journal of Economics 10(Autumn): 412-428.

Rasmusen, E.B., Ramseyer, J.M., and Wiley, J.S. Jr. (1991) Naked Exclusion. American Economic Review 81: 1137-1145.

14

Lee, Khai S. and Irene C L Ng, (2007), "An Integrative Framework of Pre-Emption Strategies," Journal of Strategic Marketing, Forthcoming 
Reynolds, S.S. (1987) Capacity Investment, Preemption and Commitment in an infinite horizon model. International Economic Review 28(1, Feb): 69-88.

Robinson, W.T. and Fornell, C. (1985) Sources of Market Pioneering Advantages in Consumer Goods Industries. Journal of Marketing Research 22(Aug): 305-318.

Robinson, W.T.; Fornell, C. and Sullivan, M. (1992) Are Market Pioneers Intrinsically Stronger than Later Entrants? Strategic Management Journal 13: 609-624.

Robinson WT., Chiang J. (2002) Product Development Strategies for Established Market Pioneers, Early Followers, and Late Entrants. Strategic Management Journal 23 (9): 885866.Schmalensee, R. (1982). Product Differentiation Advantages of Pioneering Brands. American Economic Review 72 (June): 349-365.

Schmalensee, R. (1978) Entry Deterrence in the Ready-to-eat Breakfast Cereal Industry. Bell Journal of Economics 9(Autumn): 305-327.

Schnaars, S.P. (1986) When Entering Growth Markets, Are Pioneers Better than Poachers. Business Horizons Mar-Apr: 27-36.

Selten, R. (1978) The Chain Store Paradox. Theory and Decision 9: 127-159.

Shankar, V. and Bayus, B.L. (2003) Network Effects and Competition: An Empirical Analysis of the Video Game Industry. Strategic Management Journal 24(4): 375-394.

Song, M.X.; Di Benedetto, C. A. and Zhao, Y.L. (1999) Pioneering Advantages in Manufacturing and Service Industries: Empirical Evidence from Nine Countries. Strategic Management Journal 20: 811-836.

Spence M. (1977) Entry, Capacity, Investment and Oligopolistic Pricing. Bell Journal of Economics 8: 534-544.

Spence, M. (1981) The Learning Curve and Competition. Bell Journal of Economics 12: 49-70.

Spence M. (1979) Investment, Strategy and Growth in a New Market. Bell Journal of Economics Spring: $1-19$.

Srinivasan, K. (1991) Multiple Market Entry, Cost Signalling and Entry Deterrence. Management Science 37(12, Dec): 1539-1555.

Stump, R.L. and Heide, J.B. (1996) Controlling Supplier Opportunism in Industrial Relationships. Journal of Marketing Research 33(Nov): 431-441.

Thomas, L.A. (1996) Advertising Sunk Costs and Credible Spatial Preemption. Strategic Management Journal 17: 481-498.

Tufano, P. (1989) Financial Innovation and First-mover Advantages. Journal of Financial Economics 25: 213-240.

Urban, G.L.; Carter, T.; Gaskin, S. and Mucha, Z. (1986) Market Share Rewards to Pioneering Brands: An Empirical Analysis and Strategic Implications. Management Science 32(June): 645-459. 
Von Hippel, E. (1984) Appropriability of Innovation Benefit as a Predictor of the Functional Locus of Innovation. Massachusetts Institute of Technology. (Working Paper \#1084-79).

Wernerfelt, B. (1985) Brand loyalty and user skills. Journal of Economic Behavior and Organization 6: 381-385.

Wernerfelt, B. (1991) Brand Loyalty and Market Equilibrium. Marketing Science: 229-243.

White, A.P. (1983) The Dominant Firm: A Study of Market Power. UMI Research Press: Ann Arbor MI.

Williamson, O.E. (1979) Transaction Cost Economics: The Governance of Contractual Relations. Journal of Law and Economics 22(2, Oct): 233-261.

Williamson, O.E. (1981) The Economics of Organization: The Transaction Cost Approach. American. Journal of Sociology 87(3): 548-577.

Yip, G.S. (1982) Gateways to Entry. Harvard Business Review. 60 (September/October): 85-92.

Yong, J.S. (1996) Excluding Capacity-Constrained Entrants Through Exclusive Dealing: Theory and Application to Ocean Shipping. The Journal of Industrial Economics 44(2): 115-129. 
Table 1: Review of Literature on Pre-emption Based on Cost Superiority

\begin{tabular}{|l|l|}
\hline \multicolumn{1}{|c|}{ Study } & \multicolumn{1}{c|}{ Bases of Pre-emption } \\
\hline $\begin{array}{l}\text { Rao and Rutenberg, } \\
\text { Theoretical Study }\end{array}$ & $\begin{array}{l}\text { Pioneering firms gain a cost advantage over entrant due to economies of } \\
\text { scale. }\end{array}$ \\
\hline $\begin{array}{l}\text { Spence, 1981 } \\
\text { Theoretical Study }\end{array}$ & $\begin{array}{l}\text { Pioneers can create entry barriers and deter entry through costs } \\
\text { advantages created by the learning curve. }\end{array}$ \\
\hline $\begin{array}{l}\text { Milgrom and Roberts, } \\
1982 b \\
\text { Theoretical Study }\end{array}$ & $\begin{array}{l}\text { Limit pricing is a signal of an incumbent's cost efficiency, and hence deters } \\
\text { entry. }\end{array}$ \\
\hline $\begin{array}{l}\text { Robinson and Fornell, } \\
1985 \\
\text { Empirical Study }\end{array}$ & $\begin{array}{l}\text { Pioneers obtain cost advantages through savings in direct costs, as a result } \\
\text { of its marketing mix strategies. }\end{array}$ \\
\hline $\begin{array}{l}\text { Masson and Shaanan, } \\
1986 \\
\text { Empirical Study }\end{array}$ & $\begin{array}{l}\text { Incumbents can deter entry by signalling their cost advantage through both } \\
\text { limit pricing and excess capacity. }\end{array}$ \\
\hline $\begin{array}{l}\text { Ghemawat, 1986 } \\
\text { Empirical Study }\end{array}$ & $\begin{array}{l}\text { Pioneers gain a cost advantage over entrants due to economies of scale } \\
\text { and scope, which result from experience effects. }\end{array}$ \\
\hline $\begin{array}{l}\text { Liebermann and } \\
\text { Montgomery, 1988 } \\
\text { Conceptual Study }\end{array}$ & $\begin{array}{l}\text { Pioneers are able to acquire a cost advantage through their proficiencies } \\
\text { and the learning curve effect. }\end{array}$ \\
\hline $\begin{array}{l}\text { Miller, Gartner, and } \\
\text { Wilson, 1989 } \\
\text { Empirical Study }\end{array}$ & $\begin{array}{l}\text { Late movers are not able to achieve the cost positions of pioneers, although } \\
\text { the late movers may have to follow lower price positions. }\end{array}$ \\
\hline $\begin{array}{l}\text { Tufano, 1989 } \\
\text { Empirical Study }\end{array}$ & $\begin{array}{l}\text { Pioneers are able to capture higher market shares because they have lower } \\
\text { costs, and hence can charge lower prices. }\end{array}$ \\
\hline $\begin{array}{l}\text { Srinivasan, 1991 } \\
\text { Theoretical Study }\end{array}$ & $\begin{array}{l}\text { A low-cost pioneer operating in multiple markets can signal its low cost } \\
\text { advantage by undertaking limit pricing in all the markets served. The } \\
\text { pioneer can achieve further cost reductions by combining the costs of } \\
\text { signalling across the markets. }\end{array}$ \\
\hline $\begin{array}{l}\text { Thomas, } 1996 \\
\text { Empirical Study } \\
\text { cost in introducing new products, which provides an incentive to a pioneer } \\
\text { to introduce new products before the onset of an increase in demand. }\end{array}$ \\
\hline
\end{tabular}


Table 2: Review of Literature on Pre-emption Based on Consumers' Switching Cost

\begin{tabular}{|c|c|}
\hline Study & Bases of Pre-emption \\
\hline $\begin{array}{l}\text { Schmalensee, } 1982 \\
\text { Theoretical Study }\end{array}$ & $\begin{array}{l}\text { Pioneering brands become the standard against which future entrants are } \\
\text { judged, making it difficult for later entrants to persuade customers to invest } \\
\text { in learning about their qualities. Hence, barriers to entry are increased for } \\
\text { high-risk and low-purchase frequency products, experience and } \\
\text { convenience goods, and with increased brand awareness. }\end{array}$ \\
\hline $\begin{array}{l}\text { Conrad, } 1983 \\
\text { Theoretical Study }\end{array}$ & $\begin{array}{l}\text { When product quality is uncertain, risk-averse consumers are willing to pay } \\
\text { higher for a pioneering brand than for a later brand, because they are more } \\
\text { informed about the pioneer's quality. }\end{array}$ \\
\hline $\begin{array}{l}\text { Krouse, } 1984 \\
\text { Conceptual Study }\end{array}$ & $\begin{array}{l}\text { The creation and sustenance of brand image and reputation assures } \\
\text { customers that the necessary quality level will be provided. This is an } \\
\text { assurance that new entrants are denied. }\end{array}$ \\
\hline $\begin{array}{l}\text { Wernerfelt, } 1985 \\
\text { Theoretical Study }\end{array}$ & $\begin{array}{l}\text { Consumers' experience with a brand creates user skills that increase } \\
\text { switching costs. }\end{array}$ \\
\hline $\begin{array}{l}\text { Alpert, } 1987 \\
\text { Conceptual Study }\end{array}$ & $\begin{array}{l}\text { A pioneering advantage can be achieved by increasing brand } \\
\text { rememberability, such that it becomes an exemplar that comes to mind } \\
\text { more readily than other bands. This is most effective when the brand } \\
\text { becomes generalisable to the entire product class. }\end{array}$ \\
\hline $\begin{array}{l}\text { Klemperer, } 1986 \\
\text { Theoretical Study }\end{array}$ & $\begin{array}{l}\text { Consumer switching costs may be increased through the learning required } \\
\text { in the use of a brand, transaction costs imposed by a firm for switching, } \\
\text { consumer investments in specific equipment, and/or psychological costs } \\
\text { incurred in switching as a result of repeat purchase or habit. }\end{array}$ \\
\hline $\begin{array}{l}\text { Lieberman and } \\
\text { Montgomery, } 1988 \\
\text { Conceptual Study }\end{array}$ & $\begin{array}{l}\text { Pioneers can pre-empt entrants by increasing buyers' switching cost } \\
\text { through branding. Entry may be deterred if late entrants have to utilise } \\
\text { extra resources to persuade buyers to switch brands. }\end{array}$ \\
\hline $\begin{array}{l}\text { Carpenter and } \\
\text { Nakamoto, } 1989 \\
\text { Empirical Study }\end{array}$ & $\begin{array}{l}\text { Pioneers can frame the perceptions of the category that its product falls } \\
\text { under, such that it becomes prototypical of the category. }\end{array}$ \\
\hline $\begin{array}{l}\text { Hoch and Deighton, } \\
1989 \\
\text { Conceptual Study }\end{array}$ & $\begin{array}{l}\text { Pioneering firms can block consumers from indulging in trials of other } \\
\text { entrants by matching promotional tactics, reinforcing the brand, and } \\
\text { explaining to customers the brand satisfaction derived. }\end{array}$ \\
\hline $\begin{array}{l}\text { Neven, } 1989 \\
\text { Conceptual Study }\end{array}$ & $\begin{array}{l}\text { Brand loyalty increases customers' switching costs, and hence is effective } \\
\text { in deterring entry. }\end{array}$ \\
\hline $\begin{array}{l}\text { Wernerfelt, } 1991 \\
\text { Theoretical Study }\end{array}$ & $\begin{array}{l}\text { Brand loyalty increases customers' switching cost, and thus allows an } \\
\text { incumbent to command a larger market share. }\end{array}$ \\
\hline $\begin{array}{l}\text { Lee and O'Connor, } \\
2003 \\
\text { Conceptual Study }\end{array}$ & $\begin{array}{l}\text { Network effects might occur in certain industries (e.g. information } \\
\text { technology) and switching costs might positively depend more on network } \\
\text { size. }\end{array}$ \\
\hline $\begin{array}{l}\text { Shankar and Bayus, } \\
2003 \\
\text { Empirical Study }\end{array}$ & $\begin{array}{l}\text { Through enhancing network strength, network effects could be enhanced } \\
\text { and therefore make customers enjoy more benefits from the products. }\end{array}$ \\
\hline
\end{tabular}


Table 3: Review of Literature on Pre-emption Based on Channel Exclusivity

\begin{tabular}{|c|c|}
\hline Study & Bases of Pre-emption \\
\hline $\begin{array}{l}\text { Porter, } 1974 \\
\text { Empirical Study }\end{array}$ & $\begin{array}{l}\text { For convenience goods, a pioneer can erect barriers to entry by making it } \\
\text { difficult for potential rivals to gain access to distribution. }\end{array}$ \\
\hline $\begin{array}{l}\text { Prescott and Vischer, } \\
1977 \\
\text { Theoretical Study }\end{array}$ & $\begin{array}{l}\text { First movers can pre-empt entry by locating in as many positions (physically } \\
\text { or spatially) as feasible so that there are no remaining locations that are } \\
\text { sufficiently profitable for future entrants. }\end{array}$ \\
\hline $\begin{array}{l}\text { Schmalensee, } 1978 \\
\text { Theoretical Study }\end{array}$ & $\begin{array}{l}\text { By pre-emptively filling in attractive market niches that later entrants may be } \\
\text { attracted to, entry can be deterred. }\end{array}$ \\
\hline $\begin{array}{l}\text { Lane, } 1980 \\
\text { Theoretical Study }\end{array}$ & $\begin{array}{l}\text { Firms can prevent entry from occurring by locating themselves in several } \\
\text { entry-deterring locations. }\end{array}$ \\
\hline $\begin{array}{l}\text { Robinson and Fornell, } \\
1985 \\
\text { Empirical Study }\end{array}$ & $\begin{array}{l}\text { Pioneers can acquire a distribution advantage, and hence pre-empt entry, } \\
\text { through intensive distribution and domination of shelf-space. They can also } \\
\text { have a broad product line that occupies the positions for the largest and } \\
\text { most lucrative segments, leaving the smaller and less profitable niches to } \\
\text { later entrants. }\end{array}$ \\
\hline $\begin{array}{l}\text { Ghemawat, } 1986 \\
\text { Empirical Study }\end{array}$ & $\begin{array}{l}\text { Entry deterrence can be achieved by placing obstacles in the way of } \\
\text { potential rivals. Pioneers should attempt to acquire sustainable advantages } \\
\text { in having superior access to suppliers and preferred access to markets, and } \\
\text { restricting the options of competitors. }\end{array}$ \\
\hline $\begin{array}{l}\text { Urban et al., } 1986 \\
\text { Empirical Study }\end{array}$ & $\begin{array}{l}\text { An incumbent can deter entry by taking-up a preferred position, and } \\
\text { increasing brand advertising. }\end{array}$ \\
\hline $\begin{array}{l}\text { Liebermann and } \\
\text { Montgomery, } 1988 \\
\text { Conceptual Study }\end{array}$ & $\begin{array}{l}\text { Entry can be averted if rival perceives its inability to access scarce } \\
\text { resources to be a major obstacle. Pioneers should therefore pre-empt entry } \\
\text { through the tie up of scarce resources. }\end{array}$ \\
\hline $\begin{array}{l}\text { Neven, } 1989 \\
\text { Conceptual Study }\end{array}$ & $\begin{array}{l}\text { A pioneer can deter entry through increasing a rival's cost of entry, brand } \\
\text { proliferation, pre-emptive product location, advertising to build brand image, } \\
\text { and product design. }\end{array}$ \\
\hline $\begin{array}{l}\text { Thomas, } 1996 \\
\text { Empirical Study }\end{array}$ & $\begin{array}{l}\text { Pioneers who possess well-known brands have lower costs of introducing } \\
\text { new brand extensions. Pioneers can therefore limit the market share of } \\
\text { potential entrants by crowding the product spaces. }\end{array}$ \\
\hline
\end{tabular}


Table 4: Review of Literature on Pre-emption Based on Environmental Barriers to Entry

\begin{tabular}{|l|l|}
\hline \multicolumn{1}{|c|}{ Study } & \multicolumn{1}{c|}{ Bases of Pre-emption } \\
\hline $\begin{array}{l}\text { Gilbert and Newbery, } \\
1982 \\
\text { Theoretical Study }\end{array}$ & $\begin{array}{l}\text { Firms can pre-empt by investing in research to develop "sleeping patents" } \\
\text { which are withheld from use, but which will deny potential rivals access to } \\
\text { the technology. Continued investments in R\& can therefore serve as a } \\
\text { credible signal by an incumbent's ability to overtake any rival considering a } \\
\text { competitive research programme. }\end{array}$ \\
\hline $\begin{array}{l}\text { Bresnahan, 1985 } \\
\text { Empirical Study }\end{array}$ & $\begin{array}{l}\text { By patenting multiple new and alternative technologies, potential entrants } \\
\text { can be 'blocked' from entry. }\end{array}$ \\
\hline $\begin{array}{l}\text { Ghemawat, 1986 } \\
\text { Empirical Study }\end{array}$ & $\begin{array}{l}\text { Pioneers can deter entry by being on the right side of governmental public } \\
\text { policies. }\end{array}$ \\
\hline $\begin{array}{l}\text { Lieberman and } \\
\text { Contgomery, 1988 }\end{array}$ & $\begin{array}{l}\text { Entry can be deterred through a rival's perceptions of a pioneer's } \\
\text { technological superiority. }\end{array}$ \\
\hline $\begin{array}{l}\text { Neven, 1989 } \\
\text { Conceptual Study }\end{array}$ & $\begin{array}{l}\text { A pioneer can deter entry by denying access of potential entrants to } \\
\text { technology through patents. }\end{array}$ \\
\hline $\begin{array}{l}\text { McGahan, 1993 } \\
\text { Theoretical Study }\end{array}$ & $\begin{array}{l}\text { If entrants are kept ill-informed about demand, and hence their perceived } \\
\text { risk of entry is increased, then they can be deterred from entry. An } \\
\text { incumbent should therefore keep demand information private, or even } \\
\text { manipulate it, to influence entrant's decision. }\end{array}$ \\
\hline
\end{tabular}


Table 5: Review of Literature on Pre-emption Based on Credible Commitment to React Aggressively

\begin{tabular}{|l|l|}
\hline \multicolumn{1}{|c|}{ Study } & \multicolumn{1}{c|}{ Bases of Pre-emption } \\
\hline $\begin{array}{l}\text { Selten, 1978 } \\
\text { Theoretical Study }\end{array}$ & $\begin{array}{l}\text { By fighting entry from the outset, a firm can develop a reputation that will } \\
\text { deter later entrants. }\end{array}$ \\
\hline $\begin{array}{l}\text { Spence, 1979 } \\
\text { Theoretical Study }\end{array}$ & $\begin{array}{l}\text { Pioneers can undertake pre-emptive investments to deter entry into the } \\
\text { market. }\end{array}$ \\
\hline $\begin{array}{l}\text { Dixit, 1979 } \\
\text { Theoretical Study }\end{array}$ & $\begin{array}{l}\text { Excess capacity serves as a credible threat of lowered prices and } \\
\text { profitability post-entry. }\end{array}$ \\
\hline $\begin{array}{l}\text { Eaton and Lipsey, 1979 } \\
\text { Theoretical Study }\end{array}$ & $\begin{array}{l}\text { Capacity expansion, just at the point in time when it would be profitable for } \\
\text { entry, is profit-maximising for the incumbent and deters entry. }\end{array}$ \\
\hline $\begin{array}{l}\text { Dixit, 1980 } \\
\text { Theoretical Study }\end{array}$ & $\begin{array}{l}\text { Irrevocable commitment of investment alters the initial conditions of the } \\
\text { post-entry game to the advantage of the incumbent, and deters entry. }\end{array}$ \\
\hline $\begin{array}{l}\text { Eaton and Lipsey, 1980 } \\
\text { Theoretical Study }\end{array}$ & $\begin{array}{l}\text { Irreversible investments serve as a credible exit barrier that commits an } \\
\text { incumbent to defend its market. Hence, such exit barriers also become } \\
\text { barriers to entry. }\end{array}$ \\
\hline $\begin{array}{l}\text { Kreps and Wilson, 1982 } \\
\text { Conceptual Study }\end{array}$ & $\begin{array}{l}\text { If an incumbent has a strong reputation for being adversary over time, and } \\
\text { then the aggressive reactions can normally serve as threats to impede } \\
\text { other entries. }\end{array}$ \\
\hline $\begin{array}{l}\text { Milgrom and Roberts, } \\
1982 a \\
\text { Theoretical Study }\end{array}$ & $\begin{array}{l}\text { Entry can be deterred if a firm exhibits some behavioural rule, like being a } \\
\text { "fanatical predator". }\end{array}$ \\
\hline $\begin{array}{l}\text { Ghemawat, 1984 } \\
\text { Empirical Study }\end{array}$ & A low-cost firm can pre-empt potential entrants by adding new capacity. \\
\hline $\begin{array}{l}\text { Ghemawat, 1986 } \\
\text { Empirical Study }\end{array}$ & $\begin{array}{l}\text { Durable investments signal a pioneer's commitment to defend its market } \\
\text { against entry. }\end{array}$ \\
\hline $\begin{array}{l}\text { Heil and Robertson, } \\
1991 \\
\text { Theoretical Study }\end{array}$ & $\begin{array}{l}\text { Incumbent firms' ability to develop barriers to new entries and the credibility } \\
\text { of signals will determine the likelihood of achieving pre-emptive advantage. }\end{array}$ \\
\hline $\begin{array}{l}\text { Clark and Montgomery, } \\
1998 \\
\text { Empirical Study }\end{array}$ & \begin{tabular}{l} 
Reputation is less useful when entrants know more about incumbent firms. \\
\hline
\end{tabular}
\end{tabular}


Table 6: Pre-emption Strategies: Issues of Application

\begin{tabular}{|c|c|}
\hline Strategy & Issues of Application \\
\hline $\begin{array}{l}\text { Cost } \\
\text { Leadership } \\
\text { Strategy }\end{array}$ & $\begin{array}{l}\text { Cost leadership could arise from economies of scale and learning curve } \\
\text { effects (Karakaya and Stahl, 1989). It also can be achieved by production } \\
\text { technology upgrades and distribution efficiencies. However, new entrants } \\
\text { might able to enter the market through imitation, or even as a free rider } \\
\text { (Lieberman and Montgomery, 1988). The costs of imitation is usually lower } \\
\text { than the cost of R\&D. Incumbent firms may therefore lose their cost } \\
\text { advantage if they cannot deter imitation. In this case, incumbent firms might } \\
\text { need to apply for patents to protect their advantage. } \\
\text { If incumbent firms are not able to adapt to environmental change (e.g. } \\
\text { incumbent firms might become inflexible to the shifts of technology or } \\
\text { customer needs if they are locked in their fixed assets), potential rivals may } \\
\text { still enter. Lin and Carley (1997) pointed out that a firm with complex internal } \\
\text { structures may signal inflexibility. In this case, incumbent firms may need to } \\
\text { improve their organisational design. }\end{array}$ \\
\hline $\begin{array}{l}\text { Switching Cost } \\
\text { Strategy }\end{array}$ & $\begin{array}{l}\text { A high switching cost could enhance incumbent firms' pioneering advantage. } \\
\text { Yet, market pioneers with a network advantage might lose their advantage if } \\
\text { new entrants are able to build networks quickly (Lee and O'Connor, 2003). } \\
\text { Also, increasing switching cost by designing and establishing products as the } \\
\text { standard in the market might deter new customers from using the firm's } \\
\text { products. Furthermore, service failures might negate a switching cost } \\
\text { strategy even if an incumbent firm can build a strong brand image and loyalty } \\
\text { for its products. Finally, customers might not happy with penalties. To deter } \\
\text { customers from switching, firms should provide a fair price, good service, } \\
\text { and conduct themselves ethically (Keaveney, 1995). }\end{array}$ \\
\hline $\begin{array}{l}\text { Tie-Up } \\
\text { Strategy }\end{array}$ & $\begin{array}{l}\text { Exclusivity contracts could prevent new entries successfully (Aghion and } \\
\text { Bolton, 1987; Ramseyer, Rasmusen, and Wiley, 1991), and some empirical } \\
\text { studies also support this view (Yong, 1996; Pedro and Sicotte, 2003). } \\
\text { However, Posner (1981) argued that some exclusivity contracts may not } \\
\text { deter new competitors because incumbent firms need to compensate } \\
\text { customers for relinquishing the chance of meeting new entrants. Moreover, } \\
\text { if a market is close to perfect competition, exclusivity contracts might not } \\
\text { result in extra benefits for incumbent firms (Davies, 1986). } \\
\text { Vertical and horizontal integration might enhance the market power of } \\
\text { incumbent firms through integrating R\&D, manufacture and distribution. } \\
\text { New entrants therefore need to consider the cost and benefit of entries. } \\
\text { However, incumbent firms may need to pay the costs of vertical and } \\
\text { horizontal integration, and outside environment (such as anti-trust acts) also } \\
\text { imposes constraints on such integration. Other strategies such as } \\
\text { investments in brand-specific assets, tie-up of scarce resources, and spatial } \\
\text { pre-emption might result in costs increasing as well. Incumbent firms need } \\
\text { to take internal factors (costs and managerial problems) and outside } \\
\text { environment into account. }\end{array}$ \\
\hline $\begin{array}{l}\text { Credible } \\
\text { Commitment } \\
\text { Strategy }\end{array}$ & $\begin{array}{l}\text { Credible commitment strategy refers to conveying a credible threat of } \\
\text { aggressive reactions to entries. However, the strategy would deter entry } \\
\text { only when established companies are able to signal their reaction (Yip, }\end{array}$ \\
\hline
\end{tabular}

Lee, Khai S. and Irene C L Ng, (2007), "An Integrative Framework of Pre-Emption Strategies," Journal of Strategic Marketing, Forthcoming 


\begin{tabular}{|l|l|}
\hline $\begin{array}{l}\text { Blockade } \\
\text { Strategy }\end{array}$ & $\begin{array}{l}\text { 1982). Thus, if established companies are small and young, or they are not } \\
\text { able to build strong barriers, a credible commitment strategy might not be } \\
\text { useful. Furthermore, reputation is less useful when entrants know more } \\
\text { about incumbent firms (Clark and Montgomery, 1998) }\end{array}$ \\
$\begin{array}{l}\text { Pioneering firms might obtain pioneering advantages from patenting their } \\
\text { products or technology. Yet, technological discontinuities might provide } \\
\text { chances for new competitors (Lieberman and Montgomery, 1988). If the } \\
\text { demand for customers and the development of technology are very } \\
\text { dynamic, pioneering firms may not be able to keep their pioneering } \\
\text { advantages through patenting because new entrants might have advanced } \\
\text { technologies or better abilities to respond to customers' needs. } \\
\text { Furthermore, keeping private important demand information might not be so } \\
\text { successful, because some products are visible (e.g. car). New competitors } \\
\text { can read demand information from product designs and from other } \\
\text { information. If new competitors can provide a better price or product design, } \\
\text { demand may be influenced towards that of the new product. Finally, } \\
\text { lobbying for governmental policies might cause ethical problems and such a } \\
\text { strategy may backfire on the incumbent firm. }\end{array}$ \\
\hline
\end{tabular}


Figure 1

A Framework of Pre-emption Strategies

\begin{tabular}{|c|c|c|}
\hline Strategic & \multicolumn{2}{|c|}{ Strategic Advantages } \\
\hline Focus & Exclusivity & Cost Superiority \\
\hline Consumer & $\begin{array}{c}{[2]} \\
\text { Switching Cost Strategy }\end{array}$ & \multirow{2}{*}{$\begin{array}{c}{[1]} \\
\text { Cost Leadership } \\
\text { Strategy }\end{array}$} \\
\hline Channel & $\begin{array}{c}{[3]} \\
\text { Tie-Up Strategy }\end{array}$ & \\
\hline Internal & \multicolumn{2}{|c|}{$\begin{array}{c}{[4]} \\
\text { Credible Commitment Strategy }\end{array}$} \\
\hline Market Environment & \multicolumn{2}{|c|}{$\begin{array}{c}{[5]} \\
\text { Blockade Strategy }\end{array}$} \\
\hline
\end{tabular}

24

Lee, Khai S. and Irene C L Ng, (2007), "An Integrative Framework of Pre-Emption Strategies," Journal of Strategic Marketing, Forthcoming 
Figure 2

Pre-emption Strategies: Focus, Aim, and Means

\begin{tabular}{|c|c|c|}
\hline $\begin{array}{c}\text { Pre-emption } \\
\text { Strategy }\end{array}$ & Focus & Aim and Means \\
\hline $\begin{array}{l}\text { Cost } \\
\text { Leadership } \\
\text { Strategy }\end{array}$ & $\begin{array}{l}\text { Customers: } \\
-\quad \text { Consumers } \\
-\quad \text { Channel } \\
\text { Members }\end{array}$ & $\begin{array}{l}\text { To achieve cost advantage through: } \\
\text { - } \quad \text { Economies of Scale and Scope } \\
\text { - } \quad \text { Experience Curve } \\
\text { - Skills and Expertise Acquisition } \\
\text { - } \quad \text { Technology Upgrade } \\
\text { - Product Design } \\
\text { - } \quad \text { Sistribution Efficiency } \\
\text { Sourcing Strategy }\end{array}$ \\
\hline $\begin{array}{l}\text { Switching } \\
\text { Cost Strategy }\end{array}$ & Consumers & $\begin{array}{l}\text { To build up consumers' cost of switching to other } \\
\text { brands/products, through: } \\
\text { - Brand Equity, Loyalty, and Rememberability } \\
\text { - Increasing Consumers' Brand Specific Confidence } \\
\text { - Increasing Consumers' Brand Specific Investments in Skills } \\
\text { and Knowledge } \\
\text { - } \quad \text { Framing of Consumers' Perceptions } \\
\text { - Incentives for Repeat Purchase and Use } \\
\text { Product design, which requires supplementary products that } \\
\text { - } \quad \text { Network effects }\end{array}$ \\
\hline $\begin{array}{l}\text { Tie-Up } \\
\text { Strategy }\end{array}$ & $\begin{array}{l}\text { Channel: } \\
\text { - Suppliers } \\
\text { - } \quad \text { Channel } \\
\text { Inter- } \\
\quad \text { mediaries }\end{array}$ & $\begin{array}{l}\text { To gain channel members exclusive commitment to brand/firm, } \\
\text { through: } \\
\text { - Exclusivity Contracts } \\
\text { - Horizontal and Vertical Integration } \\
\text { - Spatial Pre-emption of Market Segments and Retail Shelf- } \\
\text { - Space } \\
\text { - Investments in Brand-Specific Assets }\end{array}$ \\
\hline $\begin{array}{l}\text { Credible } \\
\text { Commitment } \\
\text { Strategy }\end{array}$ & Internal & $\begin{array}{l}\text { To influence entry decisions through threats of aggressive } \\
\text { reactions, made credible through: } \\
\text { - Acquiring a Reputation for Toughness } \\
\text { - Signalling of Cost Superiority } \\
\text { - Pre-emptive Investments in excess capacity, capacity } \\
\quad \text { expansion, exit barriers, etc. }\end{array}$ \\
\hline $\begin{array}{l}\text { Blockade } \\
\text { Strategy }\end{array}$ & $\begin{array}{l}\text { Environmental } \\
\text { Factors }\end{array}$ & $\begin{array}{l}\text { To capitalise on or influence market environmental factors to } \\
\text { gain strategic advantages, through: } \\
\text { - Patent for Core Technology and Alternative Technologies } \\
\text { - Lobbying for favourable Public Policies } \\
\text { - Proprietary Market Information }\end{array}$ \\
\hline
\end{tabular}

